\title{
A atuação da Irmandade de Nossa Senhora do Rosário e São Benedito dos Homens Pretos (Desterro) e a figuração sociopolítica em torno das eleições 1846-1847
}

\author{
Thiago Cancelier Dias ${ }^{*}$ \\ ${ }^{1}$ Universidade Federal de Goiás, Goiânia-GO, Brasil
}

\section{RESUMO}

Analisa-se a participação da comunidade africana na eleição catarinense de 1846-1847. Discutem-se as disputas internas entre "pretos" e "crioulos" na Irmandade do Rosário e São Beneditino, os contextos que permearam os conflitos em torno da permanência de barracas e quitandas de africanos no Largo da Matriz, as perseguiçóes contra ajuntamentos de escravos e forros encabeçados pela Sociedade Patriótica (maçonaria), a presença de jesuítas e partidários conservadores na Irmandade e, por fim, a poesia política de Marcelino Antonio Dutra. Deseja-se compreender a figuração sociopolítica em torno da formação do bipartidarismo na Província de Santa Catarina e a agência social dos africanos da Irmandade nesse contexto. Palavras-chave: Irmandade do Rosário; política partidária; Província de Santa Catarina; cidadania; africanos.

\section{The actions of the Brotherhood of Nossa Senhora do Rosário e Sáo Benedito dos Homens Pretos (Desterro) and the socio-political configuration in elections of 1846-1847}

\section{ABSTRACT}

This text analyzes the participation of the African community in the Santa Catarina Province election of 1846-1847. It first discusses the internal disputes within the Brotherhood of Rosário e São Benedito and the context that shaped the conflicts around the presence of African stores in Largo da Matriz. The article then discusses the Patriotic Society's persecutions against slave gatherings and freed Africans, the presence of Jesuits and conservative supporters in the brotherhood, and finally, the political poetry of Marcelino

DOI: http://dx.doi.org/10.1590/2237-101X02104509.

Artigo recebido em 22 de julho de 2019 e aceito para publicação em 22 de janeiro de 2020.

* Doutor pela Universidade Federal de Goiás. E-mail: cancelier@hotmail.com. ORCID: https://orcid. org/0000-0001-5446-8010. 
Antonio Dutra. This article adds to our understanding of the socio-political configuration surrounding bipartisanship formation in Santa Catarina and the social agency of the African brotherhood in this context.

Keywords: Brotherhood of the Rosary; partisan politics; Santa Catarina Province; citizenship; Africans.

\section{La actuación de la Hermandad de Nossa Senhora do Rosário e São Benedito dos Homens Pretos (Desterro) y la configuración sociopolítica en torno de las elecciones 1846-1847}

\section{RESUMEN}

Se analiza la participación de la comunidad africana en la elección de Santa Catarina de 1846-1847. Se discuten las disputas internas entre "pretos" y "crioulos" en la Hermandad del Rosário y Sáo Benedito dos Homens Pretos (Desterro), los contextos que permearon los conflictos en torno a la permanencia de tiendas y fruterías de africanos en el Largo de la Matríz, las persecuciones contra asambleas de esclavos y manumisos encabezados por la Sociedad Patriótica (masonería), la presencia de jesuitas y partidarios conservadores en la hermandad, y finalmente, la poesía política de Marcelino Antonio Dutra. Se desea comprender la configuración sociopolítica alrededor de la formación del bipartidismo en la Provincia de Santa Catarina y la intervención social de los africanos de la hermandad en ese contexto.

Palabras clave: Hermandad del Rosario; política partidaria; provincia de Santa Catarina, ciudadanía; africanos.

O presente artigo investiga as eleiçôes de 1846-1847 na Província de Santa Catarina. Mais especificamente as disputas entre os potentados locais pelo apoio dos membros da Irmandade do Rosário e São Benedito na dita eleição. A documentação histórica revela que, apesar de os forros votarem apenas nas primárias e os escravos não votarem, o apoio da comunidade africana foi negociada com os partidos Conservador e Liberal. Para tal investigaçáo são analisados os contextos e trajetórias de vida de sujeitos envolvidos em disputas sociais em torno das eleiçôes e a existência de açôes políticas engajadas por membros da dita irmandade. Em específico, analisam-se as disputas internas entre "pretos" e "crioulos" pela mesa diretora da Irmandade, a presença de "brancos" e jesuítas em suas reuniôes, a mobilização dos irmãos em torno da permanência de barracas e quitandas de africanos no Largo da 
Matriz, a proibição de ajuntamentos de africanos e, por fim, a tentativa da maçonaria local em angariar o apoio dos irmãos nas eleiçôes, fato revelado na poesia política "Assembleia das Aves”, de Marcelino Antonio Dutra (1847). Pretende-se entender a formação do bipartidarismo na Província de Santa Catarina tendo em conta a agência social dos africanos da Irmandade nas eleiçóes de 1846-1847.

Percebe-se que a historiografia que analisa o período imperial brasileiro tende a considerar as eleiçóes como excludentes, visto o voto censitário e as frequentes acusaçóes de manipulação pelo governo. Em geral, a análise recai sobre as disputas entre a elite e as acusações de interferência pela Coroa, uma vez que seus candidatos venceram todas as eleiçóes. Por outro lado, a discussão em torno de quem vota, ou não, foi parâmetro na historiografia para definir a participação popular nas eleiçóes imperiais (LIMONGI, 2014).

Em torno de 13\% da população livre votava, mais de $85 \%$ dos votantes eram analfabetos e $90 \%$ deles viviam em áreas rurais (CARVALHO, 2002). As eleiçóes eram indiretas e realizadas em dois momentos diferentes: nas primárias os votantes elegiam os eleitores, os quais decidiam nas eleições secundárias os deputados e senadores. $\mathrm{O}$ voto era censitário, prerrogativa masculina e de pessoas livres. Dentre os livres havia os alforriados, que só podiam votar nas eleições primárias. Nas primárias havia, também, eleição direta para vereadores e juízes de paz (ROSAS, 2002).

José Murilo de Carvalho (2002) apresenta mecanismos sociais de controle sobre o voto, como quando o governador indica em quem os funcionários públicos deveriam votar, ou no mando pelos comandantes da Guarda Nacional sobre os soldados. Os comandantes eram escolhidos pelo governo dentro dos potentados locais, tornando a Guarda instituição de influência dos comerciantes e grandes proprietários. $\mathrm{O}$ autor apresenta o votante como alguém dependente de algum chefe local, obedecendo-o com maior ou menor fidelidade, o voto sendo um ato de obediência ou de afirmação de lealdade ou gratidão. Carvalho afirma que, principalmente nas cidades, local de menor dependência social, o voto era motivo de barganha e negociação entre votantes e chefes políticos, configurando-se com a distribuição de dinheiro, roupas, comidas, bebidas, animais e cargos públicos, podendo o votante vender seu voto para mais de um candidato.

Maria Odila Dias (2001) investiga as eleiçóes em uma escala mais micro que Carvalho, a partir da leitura de uma historiografia que pesquisa comunidades e setores marginalizados da sociedade. Sua abordagem versa sobre os homens pobres livres e sua inserção como votantes, e as negociaçóes em torno do recrutamento militar e do clientelismo no meio rural nas eleições. Ela acentua que o censo exigido para ser votante era um valor de renda anual baixo, o que incluía uma boa parcela dos homens livres. Dias analisa a participação dos homens livres pobres de área rural e identifica o uso do recrutamento para o exército como moeda de troca em torno das eleiçóes. Aqueles que não atingiam o mínimo de renda eram os preferidos para serem recrutados, maioria forra e parda. A autora indica que os estudos de 
comunidades e localidades específicas no período imperial são fonte do conhecimento sobre a história de grupos marginalizados e que compreender a inserção dos homens livres pobres no sistema eleitoral possibilita entender a resistência política à dominação. Resistência expressa na leitura das experiências de vida, reconstituindo particularidades que possibilitam aprimorar e repensar conceitos abstratos sobre a cidadania em uma sociedade escravocrata.

A discussão mais recorrente na historiografia sobre a eleição de 1846-1847, foco deste texto, versa sobre a efetividade da legislação eleitoral, o trabalho da Junta de Qualificação e as práticas locais de cooptação de votantes. A legislação indicava que a Junta de Qualificação deveria ser formada por um juiz de paz e eleitores, eleitos pelos homes livres locais. A Junta realizava a qualificação dos votantes, eleitores e candidatos e, por isso, era central no pleito e um dos momentos de acirramento político, eleiçóes eram ganhas com o controle da qualificação (LIMONGI, 2014). Na historiografia, o juiz de paz é analisado sob a ótica da centralização e descentralização administrativa, pois era cargo eletivo e possuía poderes judiciais mais amplos. Era a pessoa local eleita que atuava como conciliadora de conflitos, podendo prender e julgar transgressores, comandava as forças militares em situaçóes locais, realizava procedimentos iniciais em processos criminais e civis, em suma, proporcionou alguma autonomia aos potentados locais frente ao poder central (MOTTA, 2013). O potentado local que elege o juiz de paz e os vereadores mais votados passa a ter certo controle sobre a massa de pobres livres. Vigiando as mudanças de munícipio, identificavam os novos moradores, relatavam os desentendimentos, sabiam dos crimes, emitiam multas, em suma, vigiavam os cidadãos pobres. Era a Junta de Qualificação que controlava o recrutamento para a primeira linha do exército, por outro lado, e era eleita, também, por votantes pobres e forros, os preferidos para serem recrutados. $\mathrm{O}$ uso do recrutamento como moeda eleitoral diminuiu com a reforma eleitoral de 1856 (DIAS, 2001).

Beatriz Gallotti Mamigonian (2015) em seu estudo sobre a cidadania dos libertos africanos no Brasil afirma que há duas tendências historiográficas na discussão em torno da cidadania no período imperial. Uma primeira centrada na constituição do Estado Nacional e uma segunda no estudo das formas de participação política adotadas pelos grupos sociais. Identifica a autora três temáticas de pesquisa mais recorrentes sobre cidadania: uma primeira que investiga as bases legais estabelecidas na Constituição de 1824; uma segunda que trata da ação política dos homens livres identificadas em jornais e em manifestações urbanas; e uma terceira que relaciona a cidadania e a sociedade escravocrata na busca de compreender a participação política dos não-cidadãos (escravos), ou daqueles que não possuíam cidadania plena como os forros.

É nessa última vertente que se enquadra o texto que segue. Busca-se entender os contextos, as trajetórias e a presença da comunidade africana de Desterro nas eleiçôes de 1846-1847, grupo esse com forte estigma social, pouco monetizado, mas que a partir da sua especificidade e de uma irmandade religiosa fazia política partidária. Aparentemente é desconhecida 
pela historiografia a participação de irmandades africanas nas eleiçóes imperiais. O questionamento surgiu da leitura do poema de Marcelino Antonio Dutra chamado "Assembleia das Aves", documento central para compreender os agrupamentos políticos envolvidos na eleição catarinense de 1846-1847.

A dissertação de Rosane Cordeiro Silva (1995) é o único texto sobre o dito poema. Ela identifica que havia uma disputa política e literária envolvendo o político liberal e professor, comerciante e poeta Marcelino Antonio Dutra (1809-1869) e o conservador, professor, padre e poeta Joaquim Gomes d'Oliveira e Paiva (1821-1869). A autora elenca uma hipótese para a formação do bipartidarismo na Província que envolvia a construção das barracas e quitandas do Largo da Matriz e a fundação do Mercado Público Municipal, e conclui que essa disputa foi base para a formação de dois partidos na Província. No texto a seguir, expande-se a hipótese da autora com análise da figuração social dos grupos envolvidos na formação partidária, destacando-se a comunidade africana.

Parte-se de três autoras que constroem uma outra história catarinense, que inclui a agência de grupos subalternizados. Cláudia Mortari (2000; 2007) contribui com sua dissertação sobre a Irmandade do Rosário em São Benedito e tese sobre os vínculos familiares africanos, ambas sobre Desterro, além de transcriçôes de documentos sobre a Irmandade fornecidas. Seus textos são postos em diálogo com o de Beatriz Mamigonian (2006), que investiga as disputas internas da Irmandade e conceitualiza as diferenças identitárias do que é ser africano em Santa Catarina, constituindo um primeiro eixo de análise. Carla Laner Garcia (2006) em sua dissertação fornece dados sobre a retirada das barracas e quitandas do Largo da Matriz e o cerceamento dos africanos devido às leis sobre os ajuntamentos, constituindo o segundo eixo de análise. Um terceiro eixo é sobre os partidários conservadores e liberais e sua relação com a Irmandade do Rosário e São Benedito. Nesse momento a leitura de Oswaldo Cabral (2004) contribui para contextualizar a questão política e os políticos. A metodologia parte da leitura do livro Estabelecidos e outsiders (2000), de Norbert Elias e John Scotson, e a ideia de uma sociologia da estigmatização e a construção de uma figuração social ${ }^{2}$ a partir da microanálise.

\section{Constituição étnica e política da Irmandade de Nossa Senhora do Rosário e São Benedito}

Um dos poucos locais que era legítimo o ajuntamento de africanos era na Irmandade de Nossa Senhora do Rosário e São Benedito³. Augustin Wernet (1987) afirma que as irman-

\footnotetext{
${ }^{2}$ Federico Neiburg (2000), na apresentaçáo à edição brasileira do livro, apresenta sua leitura sobre o conceito de figuração social instrumentalizado pelos autores, aproximando-o de uma representação sobre o social criada pelo pesquisador a partir da leitura de documentos históricos e bibliografias na busca de compreender os "laços de interdependência que unem, separam e hierarquizam indivíduos e grupos sociais".

${ }^{3}$ Para uma compreensão mais abrangente sobre as irmandades do Rosário ver, dentre outros trabalhos, o de
} 
A atuação da Irmandade de Nossa Senhora do Rosário e São Benedito dos Homens Pretos (Desterro) e A FIGURAÇÁO SOCIOPOLÍTICA EM TORNO DAS ELEIÇÓES I 846-I 847

Thiago Cancelier Dias

dades serviam como instituiçôes que atenuavam os conflitos e a violência do sistema escravocrata. Em igrejas próprias ou agregadas a outras irmandades, essas instituiçóes religiosas leigas cumpriam um papel referente ao Estado e à Igreja, estavam presentes tanto nos rituais de passagem da vida religiosa católica quanto da vida civil.

As irmandades e confrarias em geral eram símbolos de distinção social, assim sendo para além do caráter religioso, eram espaço de fazer político e de relaçóes comerciais. Ter escravos em uma irmandade poderia ser rendoso ao escravista, pois um escravo ladino que seguisse preceitos católicos e falasse português tinha valor maior de mercado. Pelo lado do escravo, ser de uma irmandade seria uma maneira de atenuar sua situação de cativo, pelo abrandamento de seu estigma social e pela maior capacidade de usufruir mecanismos de salvaguarda, baseados em relações de solidariedade. O Compromisso de 1842 fornece alguns indícios dos mecanismos de salvaguarda que os africanos e descendentes poderiam esperar de sua associação à Irmandade. Nesse regimento consta que se deveria sepultar e sufragar os irmãos falecidos, cuidar da educação dos órfãos e promover a liberdade dos irmãos cativos (com uso do recolhimento de esmolas) (MORTARI, 2000).

$\mathrm{Na}$ documentação sobre a Irmandade é possível encontrar uma hierarquização social construída a partir da "qualidade" do sujeito, ou seja, embasada em classificaçôes feitas com critérios baseados na cor, condiçáo social e status. Classificação dinâmica, ao ponto de uma mesma pessoa poder ser "seletivamente reclassificada, 'embranquecendo', se ganhasse status, ou escurecendo', se perdesse" (MAMIGONIAN, 2006, p. 626-627).

É plausível supor que no local e período que delimitam a pesquisa ser considerado ou ser percebido como preto significava ser africano, podendo ser de condição forra ou escrava. Por sua vez o termo crioulo indica os sujeitos de condição escrava, nascidos no Brasil. A designação pardo é atribuída, na maioria das vezes, àqueles sujeitos de condição forra nascidos no Brasil, mas que possuem a descendência africana e a marca da escravidáo passada. Dito de outra forma: os termos preto, crioulo e pardo significam tanto cor quanto origem e condição social. Preto: cor, origem africana, condição de escravo ou forro; crioulo: cor, origem afrodescendente, condiçâoo escrava; pardo: cor, origem afrodescendente, condição forra, preferencialmente (DIAS, 2008).

Essas identificaçôes eram voláteis e dependiam das estratégias e contingências das pessoas envolvidas, desde os sujeitos da ação até os redatores dos documentos que descrevem a ação. Dependendo da situação e momento as pessoas eram classificadas ou levadas a assumir identificações diferentes. Essas identificaçôes fragmentadas e construídas ao longo dos discursos dependiam dos recursos materiais e simbólicos envolvidos. Possuíam força pela sua capacidade de excluir o outro, transformando o diferente em exterior, estabelecendo uma hierarquia que define o nós e os outros. Essa política de exclusão, identificaçáo ou estabelecimento de diferença, dizia quem era quem, através de fronteiras simbólicas

Julita Scarano (1978), Célia Maia Borges (2005) e Leonara Lacerda Delfino (2015).

Topoi (Rio J.), Rio de Janeiro, v. 21, n. 45, p. 732-753, set./dez. 2020 | www.revistatopoi.org 
que delimitavam os agrupamentos (HALL, 2005). A afirmação das identificaçôes e das diferenças entre as pessoas e grupos eram relaçôes de poder que traduziam "o desejo de diferentes grupos sociais assimetricamente situados, de garantir o acesso privilegiado aos bens sociais" (SILVA, 2005, p. 81).

O primeiro Compromisso da Irmandade de Nossa Senhora do Rosário e São Benedito é datado de 1750. Em 1807, é firmado um novo Compromisso que define as especificaçôes dos cargos presentes na Mesa da Irmandade. No Compromisso, as atribuiçóes do cargo de juiz foram estipuladas segundo a prerrogativa que "como a dita Irmandade é mais derivada de Homens Pretos, e desde sua fundação o Juiz dela foi Homem daquela qualidade, justo é que assim fique praticando para o futuro, fazendo-se eleição no Irmão que se conhecer de mais consideração e capacidade" (MORTARI, 2007, p. 179). Assim em um momento que o número de pretos era mais representativo que o de crioulos e pardos, a Irmandade correspondia aos desejos dos africanos, ou pretos, de deter o cargo de comando.

Os pretos tiveram sua hegemonia contestada por um agrupamento formado por crioulos, quando eles originaram a Irmandade de Nossa Senhora do Parto de Irmáos Crioulos em 1833. A Irmandade do Parto, nesse ano, aloca a imagem de sua padroeira em uma das paredes laterais da Igreja da Irmandade de Nossa Senhora do Rosário e São Benedito. Ficou estabelecido um acordo no qual é definido que a possível transferência da imagem para outra igreja era de responsabilidade do tesoureiro da Irmandade do Rosário, que também ficou responsável pelos bens da Irmandade do Parto e pelas esmolas recolhidas pelos seus irmáos (MORTARI, 2000).

Alguns irmãos crioulos obtêm com o governo provincial a autorização para transferir a imagem da sua padroeira para a Igreja Matriz em 1837 (MAMIGONIAN, 2006). Os crioulos conseguem também a permissão do governo para construir sua capela na rua do Príncipe, no Bairro Figueira. Em contrapartida o arcipreste nega o pedido de transferência para a Igreja Matriz (MORTARI, 2000). Com a negação, o juiz entra em contato com o Vigário Capitular ${ }^{4}$ do Rio de Janeiro, que deliberou a favor do retorno da padroeira para a Igreja do Rosário (MAMIGONIAN, 2006).

Um conflito entre esferas de poder ocorre, por um lado, entre as autoridades que deliberavam em favor dos irmáos crioulos, enquanto as autoridades eclesiásticas em favor da mesa diretora da Irmandade do Rosário e Sáo Benedito. As irmandades leigas respondiam aos poderes civis e eclesiásticos. As autoridades civis entendiam que a hierarquia eclesiástica tinha delegação somente sobre as coisas sacras. Já as autoridades eclesiásticas, muitas vezes, percebiam-se como plenos responsáveis sobre essas associaçôes religiosas católicas.

Os irmãos do parto conseguem, em 1838, autorização com o juiz de paz de Desterro para esmolar em prol da construçáo de sua capela, em vez de entregar ao tesoureiro do Ro-

\footnotetext{
${ }^{4}$ Vigário Capitular era a designaçáo do padre que tinha o direito a voto nas assembleias eclesiásticas feitas no Brasil para decidir sobre questóes internas da hierarquia católica.
} 
sário e São Benedito como firmado inicialmente. A mesa diretora da Irmandade do Rosário tentou cassar as autorizaçóes com os eclesiásticos responsáveis. Desejava, também, que a padroeira saísse da Capela de Nossa Senhora do Rosário somente quando a Capela de Nossa Senhora do Parto estivesse pronta. Ao que parece, alguns irmãos crioulos queriam seu espaço próprio. A liderança contra essa secessão foi feita pelo pardo Luiz de Miranda Ribeiro, Juiz da Irmandade do Rosário e São Benedito. Ele ocupou por vários anos o cargo de juiz (1838-1841), apesar de o compromisso de 1807 estipular que o juiz deveria ser "homem preto". Deliberou contra os crioulos diretamente ao Vigário Capitular do Rio de Janeiro contra a construção da capela e contra o não repasse das esmolas recolhidas pelos irmãos crioulos (MAMIGONIAN, 2006).

Antônio Gomes da Luz e Luís Meireles deliberaram uma ação judiciária contra o Juiz Luiz de Miranda Ribeiro por causa do novo Compromisso5. Alguns meses depois, o Cônego e futuro Arcipreste Manoel Alves de Toledo (1845-1851) propôs a exclusão de alguns pretos da nação mina envolvidos por "por terem semeado a discórdia"6. A mesa aprovou prontamente, entrementes, na prática, eles se mantiveram na Irmandade, assumindo em outras eleiçóes lugar na mesa, enquanto o cônego não se apresentou mais à Irmandade, mesmo quando convocado. Indício de que náo era bem-vindo.

A resistência na mudança de compromissos era porque os pretos não aceitavam que os escravos fossem excluídos legalmente do cargo de juiz por não terem "alguma representação civil” (MAMIGONIAN, 2006, p. 611), demonstrando uma disputa pela mesa diretora. Os irmãos pretos estavam prestes a perder o domínio da Irmandade e, por isso, enviaram um requerimento à autoridade eclesiástica:

conforme o Compromisso da dada Irmandade, e costume imemorial á seguramente oitenta anos, tudo isso se resulta a frívolos pretextos agitados por um punhado de mulatos e crioulos, que apoiados por algumas pessoas se tem descaradamente quer uns, quer outros, e que mesmo os apoiadores, conspirado contra a dada Irmandade de Pretos da Costa, sempre, e sempre os primeiros nela constituídos, tanto em Portugal quanto neste nosso Império. ${ }^{7}$

A mudança no Compromisso foi uma adequação a um movimento que paulatinamente ocorria em todo o país. A partir da segunda metade do século XVIII, as irmandades eram impedidas de fazer distinçóes por critérios de pureza do sangue. Os cargos de autoridade deveriam ser divididos sem distinção entre os participantes. Com a Independência do Brasil, os cargos paulatinamente passaram a ser distribuídos por critério de cidadania, ou seja, ter representatividade civil, não ser escravo. Destaca-se no Compromisso de 1842 a exigência de

\footnotetext{
${ }^{5}$ Arquivo da Irmandade de Nossa Senhora do Rosário (doravante AINSR), 28 fev. 1841, p. 79 (verso).

${ }^{6}$ AINSR, 15 abr. 1841, p. 81.

${ }^{7}$ AINSR, 5 out. 1841 apud Mortari (2007, p. 181).
} 
o juiz ser homem de "possibilidade e caráter", ou seja, ter renda e atender os preceitos morais católicos (MAMIGONIAN, 2006).

Os irmãos pretos não tiveram sucesso nas reivindicaçóes, pois o Compromisso foi mudado com a autorização da Assembleia Legislativa e do bispo do Rio de Janeiro. Os pretos entrementes detiveram os principais cargos da Irmandade após 1842. Apesar de toda movimentação dos crioulos contra alguns pretos, os africanos acabaram reassumindo a direção da Irmandade. O preto Antônio Gomes da Luz não é expulso, pelo contrário, foi eleito juiz nos anos de 1842, 1843 e 1844. Já Luís José Pereira Meireles foi juiz nos anos de 1846 e 1847, enquanto o preto Francisco de Quadros, em 1845, 1848, 1850 e 1852. A leitura da documentação indica que os pretos excluíram os crioulos dos cargos de juiz da Irmandade ao menos até o fim da década de 1850 (DIAS, 2008). Ao que parece, a exclusão dos escravos da mesa diretora no Compromisso de 1842 foi apenas textual, pois nos anos posteriores alguns pretos escravizados assumiram o cargo de juiz do Rosário, entre eles encontra-se João Pequeno Lobo e Camilo Rosa (SIMÃO, 2008).

\section{Irmandade do Rosário e São Benedito e os ajuntamentos de africanos}

Muitas autoridades civis e eclesiásticas não viam com bons olhos os “ajuntamentos” e festas dos africanos. A proibição dos reisados no Compromisso de 1842 foi motivada pelo Bispo do Rio de Janeiro que, em linhas gerais, seguia o movimento de romanização da Igreja Católica Brasileira. O Compromisso de 1842 foi construído com negociações não só entre os irmãos, mas também entre o grupo do pardo Miranda Ribeiro e o Bispo. ${ }^{8}$

Era tradição nas Irmandades do Rosário e São Benedito realizar eleiçóes de reis e rainhas. Os reis e rainhas personificavam e presidiam as festividades em homenagem aos santos de devoção. Além de serem figuras que a comunidade negra se reportaria para resolver suas questôes internas, eram respeitadas também pelos escravistas (MAMIGONIAN, 2006). No Compromisso de 1842 há uma tentativa de quebra da tradição do reisado.

As inversóes culturais com reis e rainhas negras representavam ameaça à ordem pública, principalmente quando essas pessoas assumiam autoridade diante da comunidade negra. Mesmo contra o regimento de 1842, houve a festa de reis em noites consecutivas em 1843. A Câmara Municipal de Desterro, em seu código de posturas, proibiu os reisados três anos após o novo Compromisso: "Ficam proibidemos [sic] d'aqui em diante os ajuntamentos de escravos, ou libertos para formarem batuques; bem como os que tiverem por objetivos os supostos reinados africanos, que, por festas, costumam fazer"?

\footnotetext{
${ }^{8}$ AINSR, 12 mar. 1843, p. 94v-96.

${ }^{9}$ Lei Provincial n. 222, 10 maio 1845 apud Mamigonian (2006, p. 634). 
A proibição dos reisados era parte do movimento ultramontano de moralização do catolicismo devocional brasileiro. No caso da Irmandade do Rosário e Sáo Benedito de Desterro incluiu a presença de jesuítas a partir de 1843 e culto ao Sagrado Coração de Jesus nos anos seguintes. Os jesuítas eram parte do movimento ultramontano e, como parte de sua militância, estava moralizar as irmandades religiosas. Em 1843, os jesuítas assinaram contrato assumindo o cargo de capelâo da Irmandade. Em setembro participaram da discussão sobre a festa que seria realizada no dia 3 de outubro. Nesta, assinam um Termo de Mesa que tratava da festa do Santíssimo Rosário, no qual se ordenou que "a festa [fosse feita] no Mencionado dia (compromisso) com a solenidade: Missa Cantada, Sermão e Novena"10, ou seja, sem os reisados.

A relação entre irmãos e jesuítas aparentemente era boa até se deteriorar em 1847. Por influência dos jesuítas foi iniciada na Igreja do Rosário e São Benedito a devoção ao Sagrado Coração de Jesus. Muitos irmãos da Irmandade do Rosário e São Benedito foram contra. Como parte da reforma ultramontana, o objetivo dos jesuítas era combater o catolicismo de devoção baseado em santos, e como estratégia estava colocar a estátua do Sagrado Coração de Jesus em uma das laterais da Igreja. Alguns irmãos pronunciaram que a colocação da estátua diminuiria a devoção à Virgem Maria. O Mordomo da Irmandade leu uma carta dos padres, em uma das reunióes. Segundo Ferdinand Azevedo (1982-1983, p. 59), na carta, constava a afirmação feita pelos padres de que "este ataque contra a localização da estátua era, de fato, contra os padres, querendo que eles saíssem da Igreja".

Talvez a localização da estátua, e provavelmente o aparente apoio dos jesuítas ao candidato liberal, tenha levado os irmãos do Rosário a fazer oposição à presença jesuíta na Irmandade. A revelação do tal apoio dos jesuítas ao partido opositor aos irmãos do Rosário é descrito pelo editor desconhecido do poma de Marcelino Antonio Dutra: "até uns santos varóes, padres jesuítas, que vieram pregar a fé e a palavra do Divino Mestre, são (lá no intimo d'alma, e no segredo de seus peitos) muito bons e venerados Judeus" (EDITOR, 1847, p. VI). A partir de 1847 , ano da eleição e da publicaçáo do poema de Dutra, os jesuítas diminuíram sua presença nas Atas da Irmandade do Rosário e São Benedito, indício de que algo mudou. A relação entre as eleiçôes e os irmãos pretos do Rosário é melhor analisada a seguir.

\section{Irmandade de Nossa Senhora do Rosário e São Benedito e as contendas em torno das barracas dos pretos}

Os principais setores do governo na Província se localizavam no Largo da Matriz: a Câmara Municipal, a Igreja Matriz e o Palácio do Governo. O Largo também era espaço de comércio realizado nas barracas e quitandas. Era local onde pessoas livres, escravizados

$\overline{{ }^{10} \text { AINSR, } 2 \text { set. } 1843 \text {, p. } 98 .}$ 
e forros poderiam vender peixes, frutas e verduras para a população local, marinheiros e viajantes diversos.

Essas barracas e quitandas eram contestadas desde o ano de 1832. O jornal $O$ Catharinense, cujo dono era o maçom Jeronimo Francisco Coelho, denunciou o aspecto dos africanos que vendiam o peixe e diversos outros produtos nas quitandas, solicitando a demolição que deveria ser realizada pela Câmara, visto "o estado de ruína em que se acham, a qualidade de seus moradores (a maior parte negros e negras quitandeiras) apresenta a quem desembarca na praça, um aspecto bem triste e ridículo"11.

O jornal representava também a Sociedade Patriótica Catarinense, fundada por Jeronimo Coelho, opositora às barracas e quitandas. Em Ata da Sociedade de 1832 consta uma solicitação feita pelo maçom Patrício Antônio de Sepúlveda Everard à Câmara Municipal de Desterro. Ele era filiado à Loja Maçônica Esperança de Niterói (1822) (BARATA, 2002), provável loja originária de Jeronimo Coelho. Solicitava-se, em suas palavras, a demolição das "barracas instaladas em frente da praça, acabando-se enfim com esta guarida de vagabundos e escravos vadios". Em contrapartida deveria ser feito um novo trapiche, um arvoredo para servir de passeio público e "uma banca para a venda do peixe das citadas barracas"12. O governo da província (1838) autorizou a construçáo de uma Praça de Mercado, que deveria ficar entre as ruas do Livramento e Ouvidor em terreno da marinha, fora do Largo da Matriz, o qual foi concluído em 1851 (GARCIA, 2006).

De um lado estavam os maçons da Sociedade Patriótica que desejavam instalar as barracas e quitandas fora do perímetro urbano, do outro os comerciantes que defendiam a permanência das barracas e quitandas no Largo da Matriz. A motivação dos comerciantes em defesa da permanência foi o fato de temerem perder freguesia com a retirada das barracas e quitandas. A visita de Dom Pedro II e do Bispo do Rio de Janeiro (1845) levou a Câmara de Desterro a tomar medidas que iam ao encontro das solicitaçóes da Sociedade Patriótica. $\mathrm{O}$ centro urbano foi higienizado e as barraquinhas foram removidas para as proximidades do Largo Santa Bárbara, junto à Ponte do Vinagre, fora do perímetro urbano (voltaram no ano posterior ao local de origem) (GARCIA, 2006).

No mesmo ano foi reforçada a perseguição aos ajuntamentos de africanos, as Posturas Municipais passaram a estabelecer limites aos escravos e forros quanto à permanência nas casas comerciais, com multas àqueles que as descumprissem. As barracas e quitandas eram locais de encontro da comunidade africana e, portanto, de afazeres dos irmãos do Rosário e São Benedito. Local em que os escravos e forros se encontravam para trabalhar, conversar, cantar, tocar e dançar, beber e comer, fazer compras ou vender produtos. Observa-se, pois, que as Posturas afirmam:

\footnotetext{
${ }^{11}$ O Catharinense, 25 jan. 1832 apud Garcia (2006, p. 87).

${ }^{12}$ Ata da Sociedade Patriótica Catarinense, 29 abr. 1832 apud Garcia (2006, p. 86-87).
} 
Todo vendeiro que consentir dentro do armazém, taberna ou casa de quitanda, vadios, escravos, por mais tempo do que o necessário para a compra ou venda, ou consentir nas ditas casas de negócio, quitanda ou as suas portas ajuntamentos deles, toques, danças ou quaisquer vozerias, será multado em $10 \$ 000$ pela primeira vez, $20 \$ 000$ réis pela segunda e em $30 \$ 000$ pela terceira, ou tantos dias de cadeia quanto forem os mil réis de multa pecuniária. ${ }^{13}$

Nota-se que o mecanismo de controle da população africana em lugares públicos pelo policiamento teve início com a criação de um corpo de guardas voluntários em Desterro (1831), substituídos por uma força policial estatal em 1835. As funções dessa força policial era: "10 prender os criminosos em flagrantes, 20 dispensar os ajuntamentos de escravos e de quaisquer pessoas que com eles estejam de mistura, empregando a força se necessário" (GARCIA, 2006, p. 130). A força policial era imbuída de dispersar os escravos, retirando-os dos agrupamentos, em uma tentativa de extinguir qualquer organização grupal. Um dos primeiros Decretos da Assembleia Legislativa reitera o preconceito de época de que os escravos e forros eram promíscuos e sujos, e indica a proibição dos ajuntamentos (+/- 1835): "Fica proibido depois de anoitecer, todo o ajuntamento nas praças, ruas e estradas de quatro ou mais escravos ou libertos africanos, sós ou promiscuamente. Os que assim forem encontrados serão presos e punidos" ${ }^{14}$

Havia leis, posturas e políticas contra qualquer tipo de organização africana, com exceção da permanência em uma irmandade, o que fazia com que essa instituição fosse central na organização política e social africana. Dentre os pretos da Irmandade, destaca-se o forro Francisco de Quadros (?-1853) da Nação Benguela, como provável pivô da filiação da Irmandade ao Partido Conservador nas eleiçóes. Era um dos quitandeiros prejudicados, pois possuía uma quitanda perto do Porto, provavelmente no Largo da Matriz. Era parte de uma rede social africana maior, visto ser "dono de escravos, padrinho de outros africanos e compadre de crioulas, que escolheu por padrinhos de seus filhos homens e mulheres livres sem o estigma da escravidão, casado com uma crioula" (MORTARI, 2007, p. 187). Sua influência na comunidade escrava e forra pode ser medida pelo grande número de afilhados que tivera, em torno de 27, desses apenas dois eram forros. Francisco de Quadros ocupou o cargo de juiz da Irmandade nos anos de 1845, 1848, 1850 e 1852. Foi também irmão da mesa por 12 vezes e Procurador da Irmandade em 1841, 1842, 1843, 1846 (DIAS, 2008).

A relação entre pretos da Irmandade e comerciantes locais fica mais clara quando se analisam os cargos honoríficos da Irmandade e se identificam os escravistas que pagavam joias para seus escravos. Destes, a maioria era da família Livramento, base do Partido Conservador, também chamado de Partido Livramentista (1847). A família Livramento era uma derivação da família Costa, oriunda do casal Tomás Francisco da Costa (1729-1796) e

\footnotetext{
${ }^{13}$ Código de Posturas. Lei n. 222, de 10 de maio de 1845 apud Garcia (2006, p. 65-66).

${ }^{14}$ Decreto n. 10, fl. 13 apud Garcia (2006, p. 104).
} 
A atuação da Irmandade de Nossa Senhora do Rosário e São Benedito dos Homens Pretos (Desterro) e A FIGURAÇÃO SOCIOPOLÍTICA EM TORNO DAS ELEIÇÔES I 846-I 847

Thiago Cancelier Dias

Mariana Jacinta da Vitória (1729-?), ambos açorianos nascidos nas ilhas do Faial. O sobrenome Livramento teria sido adotado por parte da família por devoção à Nossa Senhora do Livramento ${ }^{15}$. Outros conservadores eram homenageados e ocupavam cargos na irmandade africana, tais como Manuel Joaquim de Almeida Coelho (1792-1871), João Francisco de Souza Coutinho e o Padre Joaquim Gomes d'Oliveira e Paiva. Nenhum partidário liberal foi encontrado (DIAS, 2008).

Um dos cargos mais ilustres da Irmandade era o de Juiz por Devoção. O compromisso de 1842 não especificava suas atribuiçốes. É possível, contudo, analisá-lo como sendo semelhante a um apadrinhamento da instituição, uma homenagem àqueles que contribuíam com a Irmandade, pagava-se joia pelo cargo (caridade). Pode-se pensar em sua designaçáo como estratégia política dos irmãos em agraciar a quem contribuía econômica e politicamente a favor da instituição, assim como a caridade ou o pagamento de joia pelos senhores escravistas não era somente ato de piedade, poderia ser uma maneira de agregar valor econômico ao escravo, tornando-o ladino e manso.

As referências a esse cargo aparecem sempre nos momentos em que se está tratando das eleiçóes, por ser o cargo eletivo. Não é possível saber se havia um critério claro para a eleição do juiz (a) por devoçáo, o que se percebe é que escolhiam sempre pessoas diferentes e influentes. Na maioria eram militares, comerciantes, funcionários públicos e padres. E que, com o domínio dos pretos sob a Irmandade após 1842, alguns partidários conservadores receberam o título de Juiz por Devoção, demonstrando a relação entre os pretos da Irmandade e os conservadores.

O Capitão Domingos Luís do Livramento foi eleito Juiz de Devoção de Nossa Senhora do Rosário em 1844. Uma das poucas pessoas a ser escolhida mais de uma vez foi o militar e futuro Major Manuel Joaquim de Almeida Coelho Sobrinho (1846, 1848 e 1851). Ele foi eleito na eleição provincial de 1847 e tinha o cargo na administração provincial de Juiz de Capelas e Resíduos. Era o funcionário da administraçáo pública responsável pelo bom andamento das igrejas, cultos e irmandades, ou seja, tinha influência direta sobre a administração da Irmandade. Foi também diversas vezes tesoureiro da Irmandade $(1845,1851,1854)$ e, por muitas vezes, é encontrada sua assinatura nas Atas. A sua presença na Irmandade pode ser averiguada entre os anos de 1841-1854. O seu cargo o tornava influente em todas as irmandades. Era filiado ao Partido Conservador (DIAS, 2008).

Outra pessoa que foi homenageada com o título de Juiz (a) por Devoção é o conservador conhecido por compor e tocar músicas sacras e profanas chamado João Francisco de Souza Coutinho. Nota-se que apesar de ser filiado ao Partido Conservador pertenceu à Sociedade Patriótica entre os anos de 1831-1836, logo, antes da ruptura que ocorreu na elite política

\footnotetext{
${ }^{15}$ Victor Hugo Bastos Cardoso gentilmente forneceu informaçôes que possibilitam estipular quem eram os possíveis familiares que compunham a família Livramento. Autor da dissertação As dinâmicas político-territoriais de uma comunidade periférica no sul da América Portuguesa: a ilha de Santa Catarina e seu Continente, 1680-1750 (2013).
} 
A atuação da Irmandade de Nossa Senhora do Rosário e São Benedito dos Homens Pretos (Desterro) e A FIGURAÇÃO SOCIOPOLÍTICA EM TORNO DAS ELEIÇÔES I 846-I 847

Thiago Cancelier Dias

local em 1846-1847. O nome do Padre Joaquim Gomes de Oliveira e Paiva aparece diversas vezes nas Atas da Irmandade. Esse filho de comerciante português estudou no Seminário São José, na Corte. Em 1843, abriu um colégio de ensino secundário em Desterro e, entre 1844 e 1849, foi vigário da Freguesia de São José. No período eleitoral e após se tornou ferrenho opositor dos jesuítas, aparentemente por eles terem apoiado os liberais (DIAS, 2008).

No livro de atas da Irmandade do Rosário pode ser identificada a presença dos escravos da família Livramento. O major João Luís do Livramento aparece como dono de Antonio (1841), enquanto o major e comendador Francisco Luis do Livramento pagou joia ao escravo Pedro (1843). Encontram-se ainda os escravos Caetano do Livramento e Antonio Luis do Livramento, cujo sobrenome indica a família do proprietário (1842). É citado na ata da Irmandade o capitão Domingos Luís do Livramento em 1844 (DIAS, 2008).

Como parte do fazer político próprio da situação escravista, os pretos eram aliados das famílias de comerciantes locais, formadas pelos escravistas mais antigos da Ilha, e o caminho para o diálogo foi a convivência na Irmandade. Os comerciantes queriam manter os africanos e suas barracas no Largo da Matriz, enquanto a direção da Sociedade Patriótica, de maioria maçom, não. A disputa política em torno das barracas e da liberdade de ajuntamento, em conjunto com a presença de jesuítas e de comerciantes locais na Irmandade, somando as atividades da maçonaria, eram parte da figuração política das eleiçóes de 1846-1847.

\section{Eleição de 1847 e as forças políticas retratadas no poema Assembleia das Aves}

A Constituição de 1824 criou os Conselhos Gerais da Província, substituídos por Assembleias Legislativas Provinciais a partir do Ato Adicional de 1834. O início do bipartidarismo na Província de Santa Catarina ocorreu em decorrência de divergências entre duas agremiaçóes políticas encontradas na Ilha de Santa Catarina. Os partidos políticos Conservador e Liberal se organizaram a partir da eleição de 1846-1847. Eleição que mudou a hegemonia dos liberais tanto na Província quanto na Assembleia Geral, impulsionada pela nomeação de um gabinete conservador por Dom Pedro II, e eleição de maioria conservadora na província catarinense.

O grupo liberal era em parte formado por maçons membros da Sociedade Patriótica presente em Desterro, criada em $1831^{16}$. A primeira Sociedade Patriótica criada no Brasil

\footnotetext{
${ }^{16}$ Oswaldo Cabral (2004) acredita que a Sociedade Patriótica de Desterro durou apenas de 1831 a 1835 porque o único documento encontrado por ele sobre essa associação foi um Livro de Atas, n. 4, datado de 18311834. A leitura de jornais de época e de Carla Laner Garcia (2006), entrementes, possibilitam inferir que a Sociedade Patriótica durou ao menos de 1831 até fins da década de 1860. Tem-se uma hipótese em aberto para ser respondida sobre a relação entre essas sociedades e a maçonaria, pois acredito que as sociedades eram uma forma de a maçonaria possuir representação jurídica civil e ter bens. A Sociedade Patriótica de Desterro era ligada à maçonaria: seu fundador Jeronimo Coelho foi o fundador da Loja Maçônica Concórdia (1831). Memória Política. Disponível em: http://memoriapolitica.alesc.sc.gov.br/biografia/420-Jeronimo_Francisco_Coelho. Acesso em: 28 fev. 2019.
} 
foi fundada por Antonio Borges da Fonseca no Rio de Janeiro no mesmo ano e tinha como determinação ser "instrumento de ordem, de preservação social, de orientação política, que suprisse as deficiências do Estado" (CABRAL, 2004, p. 257-258). É possível que a Sociedade Patriótica fundada em Desterro siga as mesmas designaçôes.

Em um plano nacional, pode-se afirmar que a Sociedade Patriótica era o nome dado à associação feita por políticos liberais moderados. Os liberais exaltados se filiavam à Sociedade Federal, enquanto os conservadores se filiavam preferencialmente à Sociedade Conservadora, que mudou o nome para Sociedade Militar. Oswaldo Cabral (2004) afirma que a Sociedade Patriótica de Desterro influenciou na administração pública e na política da província, e que entre 1831-1835 praticamente governou a Província de Santa Catarina. A leitura da documentação sugere que a hegemonia perdurou até a eleição de 1846.

O grupo conservador pertencia a famílias de prestígio econômico estabelecidas na Ilha desde o século XVIII, como as famílias Costa, Livramento e Luz. Famílias que trabalhavam principalmente no comércio com lojas no centro urbano de Desterro e/ou com a navegação de cabotagem entre o Rio de Janeiro, Pernambuco, Montevidéu e Buenos Aires com a província catarinense. Possuíam muitos familiares e escravos filiados a irmandades e confrarias religiosas presentes em Desterro. Esse grupo político fundou o Partido Conservador local, também conhecido como Partido Cristão ou Livramentista (1847-1860) (DIAS, 2008).

O Partido Conservador e o Partido Liberal entraram em sua primeira disputa eleitoral em 1846. O liberal Marcelino Antonio Dutra publicou o poemeto eleitoral intitulado "Assembleia das Aves" para retratar a disputa eleitoral em 1847. No prefácio é descrito que "em todo o império é ano de lutas desabridas, de intrigas, de embustes, de vexaçôes, de calúnias, de trapaças, adulaçôes, combinações, coalizões etc. etc.; é ano enfim de que foi dito, que ficão suspensas as garantias da honra e da probidade -" (EDITOR, 1847, p. I).

O poema foi impresso pela tipografia do Mercantil no Rio de Janeiro. Foi publicado com o intuito de fornecer um panorama das eleiçôes em prol do Partido Liberal e para ser declamado na chegada de Jeronimo Francisco Coelho a Desterro. O objetivo era o de informar sobre quem estava ao seu lado e quem estava contra na eleição para a cadeira da Assembleia Geral. A poesia foi declamada por Marcelino no momento em que seu candidato aportou em Desterro.

O editor (desconhecido), no prólogo, descreveu a campanha para as eleiçôes provinciais. Aparentemente a cidade estava em alvoroço pela longa duração da campanha devido à eleição ter sido adiada para 1847. Os candidatos à Assembleia Geral eram o Conselheiro Jeronimo Francisco Coelho (deputado em exercício) e o Bacharel Joaquim Augusto do Livramento. Os partidos foram apelidados, segundo o editor "por malignidade estratégica, e pela referida suspensão das garantias, os Livramentistas se apelidam a si de Cristãos, e alcunham os Jeromistas de Judeus, querendo eles assim fanatizar os símplices, e supersticiosamente incendiá-los contra seus adversários" (EDITOR, 1847, p. II). 
Os livramentistas espalhavam boatos que poderiam fomentar estigma, pois ser chamado de judeu era ser apontado como gentio, como inferior, como elemento de desintegração social, perigo aos costumes e à própria existência da Igreja Católica e da Coroa. A alcunha sobre o partido denotava heresia e subversão. A estigmatização do grupo concorrente era utilizada como instrumento político, uma das estratégias mais usadas na disputa por recursos e poder. A inferiorização do outro é arma nas disputas por poder como meio de ter a superioridade social (ELIAS; SCOTSON, 2000). Em Santa Catarina as estigmatizaçóes opunham grupos diferenciados pela cor, status e condição social. Como no caso da Irmandade, em que os pretos estigmatizavam os crioulos chamando-os de mulatos, assim como quando os brancos se dividiam em partidos políticos e alcunhavam para si como cristão, enquanto o outro como judeu.

Os grupos que formaram os partidos lutavam pela hegemonia política e pelas fontes de recursos que a eleição angariava. Aqueles que dominavam politicamente o governo provincial possuíam, em suas mãos, a possibilidade de criar leis, indicar cargos ao Presidente da Província, como os de delegado, subdelegado, juiz de órfãos, vigário e inspetor da instrução pública e inspetor da colonização, e influenciar nos contratos feitos com o governo, como o do uso do teatro, os realizados com as tipografias para publicarem informaçóes oficiais em seus jornais, para suprir a alimentação dos presos da cadeia pública, os remédios e alimentos do Hospital da Caridade, a alimentação e estadia das tropas. As indicaçóes políticas e contratos com a Coroa eram disputados pela elite socioeconômica e intelectual catarinense, e eram definidos na eleição.

O editor da poesia descreveu a campanha em torno das eleiçóes. Em suas palavras "os partidos foram gladiar-se na imprensa da corte; ali tem gemidos os prelos por vezes repetidas, e a polêmica tornou-se viva, animada, e forte, e ultimamente interessante e faceta". Vários ambientes foram palcos das discussões políticas, pois "formam-se também reunióes populares á céu aberto, verdadeiros meetings á inglesa". Foram utilizados "hinos, cânticos, poesia, e música, bailes, sarais, passeios, romarias, e cavalgatas, tudo exclusivo para cada lado" (EDITOR, 1847, p. IV). O editor destacou a "qualidade" e a cidadania dos partidários:

Moços, e velhos, grandes e pequenos, homens, e mulheres, meninos e meninas, casados, ou solteiros, bonitos, e feios, altos e baixos, gordos e magros, tortos e aleijados, surdos, ou cegos, sem distinção de sexo, idade e cor, estado, condiçáo, religiaao, profissão ou senão, (salvas as já ditas excepçóes), todos se afervoram, todos discutem, todos se empenham, todos trabalhão, todos, cada qual pelo seu partido, tomam a parte mais ativa e decidida, todos enfim, votantes e não votantes [...][Grifo meu] (EDITOR, 1847, p. IV-V).

Marcelino Antonio Dutra fez na poesia uma alegoria, como se fosse uma assembleia legislativa de aves. $\mathrm{O}$ texto foi publicado e recitado com o intuito de fornecer a Jeronimo 
Coelho um panorama sobre as eleiçôes que se seguiam, avisando-o das pessoas e grupos que estavam a favor de sua candidatura ou contra. Aparentemente, o contexto que permeia o poema é o de conflito em torno da hegemonia política da Sociedade Patriótica, a qual por vezes elegeu Jeronimo Coelho como deputado para a Assembleia Geral. Em oposição à sua reeleição estava o grupo de Joaquim Augusto do Livramento, apoiado por comerciantes e parte do clero.

Marcelino apresentou a ruptura que deu origem às agremiaçóes políticas como sendo traiçáo a um acordo preestabelecido que foi quebrado pela cobiça do grupo adversário. $\mathrm{Na}$ poesia utiliza da estigmatização como ferramenta política de diferenciação. O editor do livro descreveu a escolha alegórica como o "Cisne, para representar o seu herói, e a do Quero-quero, para representar o rival; ambos aves aquáticas, o que bem quadra aos dois candidatos, filhos de uma província eminentemente marítima e fluvial, com a diferença porém que o Cisne é o majestoso rei dos grandes lagos, e o Quero-quero o mariscador dos pequenos charcos" (EDITOR, 1847, p. V). O que se quer destacar nesse poema, para além das disputas entre as elites socioeconômicas, é a participação da comunidade africana na eleição. No argumento do canto II há uma pista:

Para ao Cisne disputar

Popularmente afeiçóes;

Chamam as reunióes

\section{Negras aves d'ultramar}

Vão ali fezes vazar

\section{Aves de bico daninho;}

Aos Céus invoca um Arminho

Que a terra o Cisne trouxesse;

Uma corveta aparece;

Traz o Cisne ao pátrio ninho

[grifos meus] (DUTRA, 1847, p. 9).

Jeronimo Coelho antecipou sua vinda a Desterro e um dos motivos provavelmente foi o apoio dado pela comunidade africana ao Partido Conservador nas eleiçóes. No prólogo da poesia está escrito pelo editor que os liberais chamaram as "negras aves" para uma reunião, momento em que foi pedido o apoio para as eleiçóes que se seguiam. Os africanos foram à reunião, mas, ao se interpretar o poema de Dutra, pode-se inferir que não apoiaram os liberais, saindo da reunião a "fezes vazar", ou seja, divulgaram a reuniáo secreta para os adversários conservadores. Na nota de rodapé escrita por Dutra, lê-se o seguinte: "refere-se ao grupo de pretos libertos, e muitos d'eles Africanos que foram associados ao club Cristáo" (DUTRA, 1847, p. V). 
A questão é: qual a importância de pessoas que na sua maioria não eram eleitores devido ao voto censitário, ou por serem escravos? Como esse grupo poderia influenciar nas eleiçôes? A estrofe seguinte tem outras pistas.

$7^{\mathrm{a}}$

\section{Negras aves africanas}

Que de-Anús - o nome tem,

Aos Surucuás, e Tucanos [conservadores]

Se reuniram também.

$8^{\mathrm{a}}$

Desta liga monstruosa

Fez-se um clube eleitoral;

Temeu logo as consequências

$\mathrm{O}$ poder policial

$9^{\mathrm{a}}$

Eis ordena que de dia

Só se possam reunir, pois da noite o negro manto

Soes os crimes encobrir

[grifos meus] (DUTRA, 1847, p. 10).

Por qual motivo um partido político faria reuniōes com a presença de pessoas sem direito a voto efetivo, com mínimas possessóes e com péssimo estigma? Um indício está na frase "aves de bico daninho". A hipótese é que a frase está relacionada à capacidade de estigmatização da comunidade africana e descendente a partir do boato. É plausível afirmar pela leitura dessas estrofes que o boato era uma arma política disponível aos escravos, forros e população em geral. No seguir do poema fica mais claro em que ponto a comunidade africana exercia ações políticas:

$10^{\mathrm{a}}$

Tinha a Fama por cem bocas

Falsamente apregoado

Todo o caso; até se afirma

Que mentira seu bocado

$11^{\mathrm{a}}$

Si uma boca só que mente,

Muito mal faz produzir,

Que de males não resultam

De cem bocas a mentir? 
$12^{\mathrm{a}}$

Soube o eleito na Corte

Do trama na terra urdido

Por muitos, que só favores

Dele haviam recebido

(DUTRA, 1847, p. 11).

O boato pode ser caracterizado como a disseminação de "informações mais ou menos depreciativas sobre terceiros, transmitidas por duas ou mais pessoas umas às outras" (ELIAS; SCOTSON, 2000, p. 121). O boato depreciativo pode incutir algo semelhante a uma desonra grupal sobre aqueles que pertencem ao grupo que sofre a estigmatização. Esse tipo de fenômeno por um lado estigmatiza o outro, por outro serve para reafirmar elementos de fomentação de carisma grupal em relação ao próprio grupo. A valorização dos membros do próprio grupo é uma relação de solidariedade, que distingue quem pertence ao grupo e quem não.

No poema, Dutra demonstra que havia receio de que os africanos que rejeitaram a aliança com os liberais poderiam junto aos conservadores disseminar informaçóes capazes de macular o Partido Liberal. O fato de ambos os partidos políticos pedirem apoio aos africanos mostra que eles possuíam uma integração grupal considerável, capaz de propiciar o uso do boato como instrumento político. Os africanos estavam em todos os ambientes que demandassem mão de obra, pois construíam, consertavam, carregavam, plantavam e colhiam, cozinhavam, compravam e vendiam. Tinham contato direto com os senhores(as) escravistas, muitos eram escravos urbanos de ganho, outros passavam o dia servindo na casa senhoril, momento que poderiam disseminar informaçóes capazes de interferir na eleição. $\mathrm{O}$ boato adquiriu força ao identificar o Partido Liberal como sendo composto por judeus. Enquanto o mais provável era ser formado por maçons, o que não deveria ser de conhecimento comum, pois a maçonaria era proibida pelo Vaticano. Talvez esteja nisso a força do boato.

A hipótese é que as controvérsias em torno das barracas no Largo da Matriz levaram Francisco de Quadros e seus companheiros da Irmandade dos pretos a lutar pelo seu meio de subsistência que estava em perigo (barracas e quitandas), contra o controle dos ajuntamentos, e a se contrapor à moralização ultramontana proposta pelos jesuítas e Bispo do Rio de Janeiro. Tal direcionamento pode ter influenciado a ligação ao Partido Conservador, visto que a Irmandade fornecia subsídios para os africanos se organizarem.

\section{Considerações finais}

O apoio dos africanos aos conservadores na eleição de 1846-1847 pode ser compreendido pela agência política dos irmãos pretos em defender o domínio sobre a Irmandade em 
torno da luta pelo abrandamento da fiscalização relativa aos ajuntamentos, na defesa pela permanência das barracas no Largo da Matriz e devido à presença de familiares conservadores na Irmandade após 1842. O apoio ao Partido Conservador poderia propiciar ganhos cotidianos na vida dos escravos e forros, pois se tratava das famílias mais numerosas, ricas, escravocratas e há mais tempo estabelecidas em Santa Catarina. O boato e a decorrente estigmatização eram arma política comum entre grupos opositores e o seu uso pelos africanos demonstra que havia interesses comuns que propiciavam solidariedade grupal, mesmo em uma sociedade excludente.

\section{Fontes documentais}

AINSR (Arquivo da Irmandade de Nossa Senhora do Rosário, doravante AINSR), Livro de Atas, 1816-1861: Termo de Mesa, 28 fev. 1841, p. 79 (verso).

AINSR. Livro de Atas, 1816-1861. Termo de Mesa, 15 abr. 1841, p. 81.

AINSR. Livro de Atas, 1816-1861. Termo de Eleição, 12 mar. 1843, p. $94 \mathrm{v}-96$.

AINSR. Livro de Atas, 1816-1861. Termo de Mesa, 2 set. 1843, p. 98.

AZEVEDO, Ferdinand (SJ). Jesuítas Espanhóis no Desterro. Revista do Instituto Histórico e Geográfico de Santa Catarina. Florianópolis, 3a Fase, n. 4, p. 7-75, 1982/1983.

\section{Referências}

BARATA, Alexandre Mansur. Maçonaria, sociabilidade ilustrada e independência do Brasil, 1790-1822. Tese (Doutorado em História). Campinas: UNICAMP, 2002.

BORGES, Célia Maia. Escravos e libertos nas Irmandades do Rosário: devoção e solidariedade em Minas Gerais dos séculos XVIII e XIX. Juiz de Fora: editora da UFJF, 2005.

CABRAL, Osvaldo. História da politica em Santa Catarina durante o Império. Florianópolis: EDUFSC, 2004.

CARVALHO, José Murilo de. Cidadania no Brasil. O longo caminho. 3. ed. Rio de Janeiro: Civilização Brasileira, 2002.

DELFINO, Leonara Lacerda. O rosário dos irmáos escravos e libertos: fronteiras, identidades e representações do viver e morrer na diáspora Atlântica. Freguesia do Pilar-São João Del-Rei (1787-1841). Tese (Doutorado em História). Juiz de Fora: UFJF, 2015.

DIAS, Maria Odila Leite da Silva. Sociabilidades sem História: votantes pobres do Império,1824-1881. In: FREITAS, Marcos Cézar (org.). Historiografia brasileira em perspectiva. 4 ed. São Paulo: Contexto, 2001. p. 57-72. 
A atuação da Irmandade de Nossa Senhora do Rosário e São Benedito dos Homens Pretos (Desterro) e A FIGURAÇÁO SOCIOPOLÍTICA EM TORNO DAS ELEIÇÔES I 846-I 847

Thiago Cancelier Dias

DIAS, Thiago Cancelier. Questão religiosa catarinense (1845-1865): as disputas pelo direito de instruir. Dissertação (Mestrado em História). Florianópolis: UFSC, 2008.

DUTRA, Marcelino Antonio. Assembleia das aves: poemeto em quatro cantos dedicado aos verdadeiros amigos do Exm $^{\circ}$ Sr. Conselheiro Jeronimo Francisco Coelho. Rio de Janeiro: Typografia do Mercantil, 1847.

EDITOR. Prólogo. In: DUTRA, Marcelino Antonio. Assembleia das aves: poemeto em quatro cantos dedicado aos verdadeiros amigos do $\mathrm{Exm}^{\circ}$ Sr. Conselheiro Jeronimo Francisco Coelho. Rio de Janeiro: Typografia do Mercantil, 1847.

ELIAS, Norbert; SCOTSON, John L. Os estabelecidos e os outsiders: sociologia das relaçóes de poder a partir de uma pequena comunidade. Rio de Janeiro: Jorge Zahar, 2000.

GARCIA, Carla Laner. Emanaçôes perniciosas, moralidade corrosiva: os desdobramentos do discurso científico no centro urbano de Nossa Senhora do Desterro (1831-1864). Dissertação (Mestrado em História). Florianópolis: UFSC, 2006.

HALL, Stuart. Quem precisa da identidade? In: SILVA, Tomaz Tadeu (org). Identidade e diferença: a perspectiva dos Estudos Culturais. 4. ed. Petrópolis: Vozes, 2005. p. 103-119.

LIMONGI, Fernando. Revisitando as eleiçóes do segundo reinado: manipulação, fraude e violência. Lua Nova, São Paulo, n. 91, p. 13-51, 2014.

MAMIGONIAN, Beatriz G. Africanos em Santa Catarina: escravidão e identidade étnica (1750-1850). In: FRAGOSO, João Luis Ribeiro et al. Novas rotas do império: eixos mercantis, tráfico e relaçóes sociais no mundo português. Vitória; Lisboa; Brasília: ed. EDUFES; Instituto de Investigaçôes Cientificas Tropicais; CNPq, 2006. p. 563-594.

MAMIGONIAN, Beatriz Gallotti. Os direitos dos libertos africanos no Brasil oitocentista: entre razões de direito e considerações políticas. História, São Paulo, v. 34, n. 2, p. 181-205, jul./dez. 2015.

MEMÓRIA POLÍTICA. Jeronimo Francisco Coelho. Disponível em: http:// memoriapolitica.alesc.sc.gov.br/biografia/420-Jeronimo_Francisco_Coelho. Acesso em 28 fev. 2019.

MORTARI, Claudia. Os homens pretos do Desterro. Um estudo sobre a Irmandade de Nossa Senhora do Rosário (1841-1860). Dissertação (Mestrado em História). Porto Alegre: PUCRS, 2000.

MORTARI, Claudia. Os africanos de uma vila portuária do sul do Brasil: criando vínculos parentais e reinventando identidades. Desterro, 1788/1850. Tese (Doutorado em História). Porto Alegre: PUCRS, 2007.

MOTTA, Kátia Sausen da. Juiz de paz e cultura política no início do Oitocentos (Província do Espírito Santo, 1827-1842). Dissertação (Mestrado em História). Vitória: UFES, 2013. ROSAS, Suzana Cavani. Eleições, cidadania e cultura política no segundo reinado. Clio: 
A atuação da Irmandade de Nossa Senhora do Rosário e São Benedito dos Homens Pretos (Desterro) e A FIGURAÇÃO SOCIOPOLÍTICA EM TORNO DAS ELEIÇÔES I 846 -I 847

Thiago Cancelier Dias

Revista de Pesquisa Histórica, Recife, n. 20, p. 83-101, 2002.

SCARANO, Julita. Devoção e escravidão. A Irmandade de Nossa Senhora do Rosário dos Pretos no Distrito Diamantino no século XVIII. São Paulo, Editora Nacional, 1978.

SILVA, Rosane Cordeiro. A poesia como arma politica: o satírico na Desterro do século XIX. Dissertação (Mestrado em Letras). Florianópolis: UFSC, 1995.

SILVA, Tomaz Tadeu. A produção social da identidade e da diferença. In: SILVA, Tomaz Tadeu (org). Identidade e diferença: a perspectiva dos Estudos Culturais. 4. ed. Petrópolis: Vozes, 2005. p. 73-103.

SIMÃO, Maristela dos Santos. Lá vem o dia a dia, lá vem a virgem Maria. Agora e na hora de nossa morte: a Irmandade de Nossa Senhora do Rosário e Sáo Benedito dos homens pretos, em Desterro. Itajaí: UDESC; Casa Aberta, 2008.

WERNET, Augustin. A Igreja Paulista no século XIX: a Reforma de D. Antônio Joaquim de Melo (1851-1861). São Paulo, Editora Ática, 1987. 